\title{
The Legal Standing of Ulayat Rights and Communal Rights of a Land Based on Knowledge and Kindship of Community System of the Sentani Customary Law in Jayapura Regency, Papua
}

\author{
Frans Reumi; Kadir Katjong \\ Faculty of Law, Cendrawasih University Papua, Indonesia
}

http://dx.doi.org/10.18415/ijmmu.v8i9.2982

\begin{abstract}
The purpose of this research is to show the different implementation of ulayat rights concept and the communal rights of a Land on the customary law community, after the enactment of Permen ATR/Head of BPN No. 10 of 2016., from the aspect of legal subject, object, characteristics, the validity is the same of not on the implementation based on the knowledge and the kindship system of the 9 (nine) ethnic group of customary law community in 12 (twelve) region of customary regency Jayapura, Province of Papua. This research using normative-juridical and empirical-juridical approach with a secondary legal material, observation, and interview, then the analysis has been done qualitatively which the reduction, presentation of legal material and verification. The Result showed that there are a perception differences on the government knowledge and customary law community knowledge of 9 ethnic group in 12 customary region on 4 development area of Jayapura. Especially the customary community of Sentani which are in the one of the development area, knows that the ulayat rights or communal rights is a common rights beside the individual rights, is different on its implementation. It means that for the 9 ethnic group of the customary law community of Sentani the concept of Ulayat rights are broad public rights and limited private rights to land, held and done by the head of the tribe, klen, and the main family, while the concept of communal rights is limited to the public rights and broad on the private of the land which done by the klen and the main family including the individual rights of the customary law community. The recognition of both differences of the concept on the implementation of ulayat rights and communal rights of 9 tribal ethnic group of Sentani on 12 sub-region of customary area of Jayapura, based on the knowledge and the legal system of kinship (the history of origin) genealogically and customary territorial and customary institution (social structure), the system of keondoafian leadership which are run until today, there are no legal certainty as the effort to overcome the differences in the concept of implementing ulayaat rights and communal rights as well as individual rights of the Sentani customary law community, Jayapura.
\end{abstract}

Keywords: Customary Law Community; Ulayat Rights; Communal Rights; Customary Land

\section{Introduction}

The essence of ulayat rights and communal rights and individual rights of the customary people as creation and gifts of Almighty god to humans to be inhabited, also contains the giving of responsibility, for the life of humanity for now and for the future in the form of customary alliances or customary law community units with cultural knowledge and customary law applies according to the lifestyle of the customary law community. 
The essence of ulayat rights and or communal rights and individual rights of customary law communities as creations and gifts of God Almighty to humans to be inhabited, also contains the giving of responsibility to humans as legal subjects to manage responsibly, for human life now and in the future in the future. the form of customary alliances or customary law community units with cultural knowledge and customary law applies according to the lifestyle of the customary law community. To understand and identifying the ulayat rights and communal rights and individual rights of the customary law community of the land is the act of planning, utilization and regulating the area by the government and/or the district government to the customary community or the people who live in, also managing the natural resource with its content which included in the ulayat rights or communal rights in order to gain a sustainable prosperous life. therefore, the existence of ulayat rights or the communal rights or individual rights of customary people cannot be separated, because above the ulayat land or communal, the community has done many life activities including managing and taking a various plant or animal above the land or under the ulayat land or communal in order to gain life sustainability of the related customary community. This research used the term of customary community as the term of customary community which have the same meaning, in accordance with the draft of the Customary Community Law.

The ulayat rights or communal rights and individual rights of customary community of the land is being an important issue in the physical development process of province, district/city, and village which based on the local culture, is very need a holistic and comprehensive knowledge about one of the problem that arise and the result of the social, political, economic, legal tension in several region in Indonesia are the issue of "customary territory space which is identical to the customary rights over customary land of indigenous people". Because of the land is the main source for the prosperity life of nation and state. Everything from the usage or utilization of the land, where on the one hand state need a land for the development purposes. While on the other side, people or the indigenous people need the land for paying purposes, social attempt, culture, economy (development of agricultural, livestock, fishery production, and etc.), therefore a land known as the source of life for the people especially for indigenous people. Therefore, the lands on the live of the Indonesian people (indigenous people) mostly controlled and owned by the indigenous people which are from various ethnic groups and/or a clans/marga of certain indigenous people. The control of this indigenous lands filled with a pluralism culture and law. The various of culture and law sometimes made an obstacle and challenge on the government, public (business world) in land acquisition for the development for example: for the purposes of physical development in the business world, in the field of investment activities proceed according to the development of sustainable regional development. So that everywhere the violation of land rights as a result of competition between the needs of the government, local governments, business (companies/entrepreneurs) and the community. The rights of the land by the people known as "ulayat rights", is a rights which owned or adhere on the indigenous community because the law and culture, which gave an authority for them to control the land or known as ulayat land which on its control to be used according to their function for the survival of indigenous peoples. ${ }^{1}$

Rusdi Lublis define Ulayat Rights as stated “... the highest land control rights in customary law include all land that is included in the territory of a certain customary law community which is land that is jointly owned by its citizens". While "ulayat land" is "a land on which the "ulayat rights" of a certain customary law are located". In addition, in reality there are three types of ulayat lands based on the control, such as: 1) Nagari Ulayat Land, 2) Tribe Ulayat Land, 3) Ulayat People Land. ${ }^{2}$ Moreover, the ulayat land according to Hermayulis is a term known as the Minangkabau culture because the influence of islam before for the indigenous people is a place to live and maintain their existence to stay exist between other groups which followed. On the other side of ulayat land is a binding element for the community to stay on a place, and a determined factor real or not that the people was coming from a region, and its utilization is for the

\footnotetext{
${ }^{1}$ Pide, A. S. M. (2007).Dilema Hak Kolektif: Eksistensi \& Realitas Sosialnya pasca-UUPA.Buku Pelita Pustaka. Makassar.p. 101
} ${ }^{2}$ Ibid.

The Legal Standing of Ulayat Rights and Communal Rights of a Land Based on Knowledge and Kindship of Community System of the Sentani Customary Law in Jayapura Regency, Papua 
purpose of maintaining relation with the community who come from outside the existing customary law community. ${ }^{3}$

The juridical reference on the Article 33 paragraph (3) of the Indonesian Constitution 1945 (hereby abbreviated as UUD 1945) mandated the government as the organizer of the state to maintain the land, water, and its resource contained there is as well as possible for the greatest prosperity of the people. The term of people (rakyat) is all the people of Indonesia including the indigenous people. As for that, the study about indigenous people or customary law people, cannot be split with the existence of ulayat rights. Ulayat rights as a technical term is a rights which attached as a distinctive competence on the indigenous people, in the form of authority or controlling power and managing the land with regulate the land in its contents with the power of behavior in and out. Therefore, the recognition of the indigenous people and their rights stated on the Article 18B paragraph (2) (Second Amendments) stated that "the state recognize and respecting the customary law community units and their traditional rights as long as they are still alive and in accordance with the development of society and the principle of the State of Republic of Indonesia, which regulated by law". Also, on the Article 28I paragraph (3) (Second Amendments) stated that "the culture identity and the traditional people rights is respected in line with the development of time and civilization."

To observe more about the ulayat rights on Indonesia Law, as stated that a recognition about the existence of indigenous people with its rights stated on the Article 18B Paragraph (2) and on the Article 28I Paragraph (3) of UUD 1945, but in reality, the recognition on the indigenous people rights with its traditional rights which known as ulayat rights, sometimes inconsistent in the realization of the national development. The main thing about ulayat rights is the control of customary land with its content by the indigenous people. The control is not in term of having but limited on developing in the space of control only. This can be seen on the laws and regulation that is published on the Law No. 23 of 1997 concerning of Environmental Management, Law No. 22 of 2001 concerning of Oil and Gas, Law No. 20 of 2002 concerning of Electric Power, Law No. 21 of 2001 concerning of Special Autonomy for Papua Province, Law No. 27 of 2004 concerning of Water Resources, Law No. 18 of 2004 concerning of Plantation, Law No 38 of 2004 concerning about road. Article 33 Paragraph (3) of UUD $1945^{4}$ stated that "The land, the waters and the natural resources within shall be under the powers of the State and shall be used to the greatest benefit of the people". The Law No. 5 of 1960 Concerning of the Basic Agrarian Principle (UUPA No. 5/1960). Article 3 and Article 5 of UUPA, the ulayat rights from the groups of indigenous people can be placed on the proper place on the space of nation and space. Article 3 of UUPA stated that "the implementation of the "Hak-Ulayat" (The Communities, in so far as they still exist, shall be adjusted as such as to fit in the National and Property right of communal property of an Adat -Community) and rights similar to that of Adat-State's interests, based on die unity of the Nation, and shall not be in conflict with the acts and other regulations of higher level". While on the Article 16 Paragraph 2 of UUPA stated that "The rights on water and airspace as meant Article 4, paragraph 3 include: The right of using water, the right of breeding and catching fish. and the right of using airspace". Article 399 of the Law No. 23 of 2014 Concerning of Local Government, giving a recognition to the special district head and special autonomy district. Meanwhile, in particular, Law Number 21 of 2001 concerning of Special Autonomy for Papua Province (hereinafter abbreviated as Law No. 21 of 2001) on Chapter I General Provision on the Article 1 Letter S mention that: "Hak Ulayat is the right of association controlled by a certain adat community over a certain area, which is the living environment of its member, covering the right to utilize the land, forest and water and all their contents according to statutory regulations"; then on the Chapter XI on Article 43 Paragraph (1) untul Paragraph (5) giving a "Protection of the Indigenous People of Papua Rights" as follows:

(1) The Government of the Papua Province shall acknowledge, respect, protect, empower and develop the rights of the adat community based on the provisions of prevailing statutory regulations.

\footnotetext{
${ }^{3}$ Hermayulis. (2000). Status Tanah Ulayat menurut Hukum Adat Minangkabau. Fakultas Hukum Universitas Andalas. Padang. p. 1-3 (on Pide, A. S. M,. (2007). p. 102)

${ }^{4}$ Indonesia Constitution 1945 (Fourth Amendments)

The Legal Standing of Ulayat Rights and Communal Rights of a Land Based on Knowledge and Kindship of Community System of the Sentani Customary Law in Jayapura Regency, Papua 
(2) The adat rights referred to in paragraph (1) shall cover the ulayat right of the adat law community and the individual right of the members of the adat law community concerned.

(3) The ulayat right, if in reality is still existing, shall be exercised by the adat authority of the adat law community concerned according to the provisions of the local adat law, by respecting the control of the ex ulayat land lawfully obtained by other parties according to the procedure and based on the provisions of statutory regulations.

(4) The ulayat land and the individual land of the members of the adat law community for any purpose whatsoever shall be provided through deliberation with the adat law community and the member concerned to obtain approval on the delivery of the land required as well as the compensation.

(5) The Government of the Province, Regency/City shall provide active mediation in the effort to settle any dispute of the ulayat land and ex individual right, in a fair and discreet manner, so that a satisfactory agreement can be reached between the parties concerned.

Furthermore, with the juridical provision based on the UUPA No.5 of 1960 above, has given a recognition of ulayat rights to the ulayat land but only limited on the principle and basic provisions universally without giving a special provision for the indigenous people, even though there has been a new policy by Ministry of Agrarian/ Head of National Land Agency of the Republic of Indonesia No. 5 of 1999 concerning of Guidelines for Adjusting the Issues of Customary Rights of Indigenous Peoples is intended as the guidelines for regional, which are autonomous region according to Law No. 22 of 1999 to do a land affairs in relation with ulayat rights that still exist in the region then amendment with the Law No. 32 of 2004 and has been amendment with the Law No. 23 of 2014, can overcome the conflict (dispute) of land so far. So that in the implementation, the limitation of attitude and the recognition of the government on the rights of ulayat land and the customary law community make it not clear. With the issuance of the Minister of Agrarian/Head of National Land Agency of the Republic of Indonesia No. 9 of 2015 which amended by the Minister of Agrarian/Head of National Land Agency of the Republic of Indonesia No. 10 of 2019 concerning of Procedure for Determining Communal Rights to Land of Customary Law Communities and Communities Located in Certain Areas, an unclear things occurs between ulayat rights and communal rights from the aspects in the implementation level on the living environment of customary law communities from the aspect of legal subject, object, the characteristics and the validity is same or not based on the knowledge and the family kindship system. While on its implementation the place of ulayat rights and communal rights there's a differences in the knowledge of the customary law community which adheres to a patrilineal kindship legal system with a clan leadership system, as does the customary law community in Jayapura, Papua.

The land conflict situation especially ulayat right or communal right and individual right of the customary law communities of the land in the Papua, basically have a diversity of its indigenous people (tribes/clan/nuclear family/bari) as the legal subject which spread based on the ecology of high land culture and low land which is: 1) La Pago, 2) Mee Pago, 3) Ha Anim, 4) Tabi/Mamta, 5) Saireri (on Papua Province), 6) Bomberay dan 7) Domberai, (West Papua), as well as with the diversity systems of customary government structures, according to J.R Mansoben (1994), there are 4 types of traditional political systems, namely: 1) Big Man/ Men with Authoriy Systems. 2) Clan, 3) Kings, and 4) Mixed.

The four types of customary government systems have an important role in the control and ownership of ulayat rights or communal rights and individual rights of customary law communities to their respective lands based on knowledge, kinship systems, and customary institutions. Specifically for the region of customary law communities of Jayapura with a customary clan government system (Ondofi or with other name) are on the 12 (twelve) areas of the Tabi/Mamta, customary law community, it is necessary to identify and structuring territorial boundaries of customary and ulayat rights over ulayat land and/or study of ideal and procedural rules in the system of control, utilization, and ownership of ulayat rights over ulayat land based on indigenous knowledge, kindship law system and customary law institutions as a qualitative reference to support indentification of spatial planning areas in the four (4) development areas of Jayapura district, including the district and village areas administratively and/or quantitatively, as an initial step for the existence of "The position of Ulayat Rights and Communal Rights Based on the

The Legal Standing of Ulayat Rights and Communal Rights of a Land Based on Knowledge and Kindship of Community System of the Sentani Customary Law in Jayapura Regency, Papua 
Knowledge and Kinship Systems in the Sentani Indigenous People of Jayapura Regency", by the state in the form of regulations, Regional Regulations (PERDA).

By culture and customary law in the customary law community in Jayapura, where ulayat rights or communal rights over ulayat land in 9 (nine) customary law communities, namely: 1) Sentani Buyakha, 2) Moy, 3) Moy, 4) Tepra-Yewana Yosu, 5) Yokari, 6) Djouwwary, 7) Imbi Numbay, 8) Oktim, dan 9) Demutru and elseng on 12 (tweleve) areas of the indigenous peoples of Jayapura, namely: (1) Indigenous People of Kemtuk, (2). Indigenous People of Mooy,(3). Indigenous People of Ormu, (4). Indigenous People of Orya, and (5). Indigenous People of Sentani, (6). Indigenous People of Souwari, (7) Indigenous People of Tepera, (8 Indigenous People of Namblong, (9) Indigenous People of Yewena, (10) Indigenous People of klesi, (11). Indigenous People of Yokari, (12) Indigenous People of Yafsi Kaureh (Orya), with its limitation of control, ownership, and ulayat land utilization or communal with the prevailing cultural and legal arrangements in the regulation of spatial planning of customary areas (ulayat or communal rights over ulayat land) over land is a rule passed down in nine (9) tribal communities of Jayapura from generation to generations orally, so the clarity is very relative. Both of these things resulted in many internal and external conflict in the handling of problems related to the customary or communal rights to land in the 9 tribes of the indigenous people of Jayapura district with the government, private sector or business world (Entrepreneur/companies).

Conflicts or problems often occur resulted in the emergence of different attitudes or views between the government (bureaucrats), the indigenous peoples of Jayapura district, and the basic agrarian law (UUPA). Conflicts over customary or communal rights over land that occur from the government's side are often seen as an obstacle to development, on the part of the community, while the law only provides recognition, not regulation, giving rise to attitudes or views of the Jayapura district indigenous peoples as a form of usurpation of customary rights over land, which indigenous peoples have had for generations. As a strategic step, the regional development planning of the Jayapura district is to support the improvement of the spatial arrangement of the customary territory on the ulayat lands of the Jayapura as mentioned above. Therefore, a fundamental explanation from the cultural and legal point of view regarding ulayat or communal rights to ulayat land (spatial planning of customary areas or ulayat rights to land) is the same or fidderent, so that it is reflected "The Position of Ulayat Rights and Communal Rights Based on Knowledge and Kinship Systems in the Sentani Customary Law Community of Jayapura", on 9 tribes and 12 subcustomary areas and the Tabi Customary area with 4 (four) development areas of Jayapura, Mainly directed at:

1) Information on the spatial dimension of customary territory over the land regarding the boundaries of control and ownership of ulayat rights over land which is one of the characteristics of the sovereign authority of indigenous peoples based on knowledge and kindship system;

2) Customary territory space for natural resource potential as the basis for consideration of allocation for regional development of Jayapura district in 4 future development areas;

3) The result of the planning of the spatial boundaries of customary areas (ulayat or communal rights over ulayat land), so that it is hoped that a follow-up study of the system or cultural and legal system that has been guided so far as the basis for the preparation of regional regulations (PERDA) regarding Ulayat Rights and Communal Rights of Indigenous People based on Knowledge and Kinship System of Indigenous People in Jayapura" on 9 tribes in 12 (twelve) indigenous people territory in a holistic and comprehensive manner.

4) With an effort to integrate the spatial planning of the 12 (twelve) areas of the indigenous peoples of Jayapura, it is hoped that it can reduce or overcome prolonged horizontal and vertical conflict (dispute) between 9 tribes of indigenous peoples, government (bureaucrats), and business (entrepreneur/company).

So that, it can streamline and organize customary spatial planning for the regional spatial plan (RT/RW) of Jayapura as the basis for planning sustainable development of the Jayapura city development based on local wisdom by refereeing to the real condition of regional potential, socio-cultural, economy, and aspiration of 9 ethnic group of Jayapura.

The Legal Standing of Ulayat Rights and Communal Rights of a Land Based on Knowledge and Kindship of Community System of the Sentani 
In 12 (twelve) region of indigenous people of Jayapura, the rights of control and ownership of ulayat or communal lands have always been regulated in such way at the tribal, clan, and family, so that each people and their family consist of tribal and clan group, giving the right to citizen to be able to use them. The ownership of ulayat land then known as customary rights or collective rights (ulayat rights/ulayat land) are held by tribes, clan, where this right gives freedom to every member or member of indigenous peoples in 12 areas of the indigenous peoples of Jayapura district as customary alliances or customary community units to freely used their lands continuously, in order to meet the needs of daily life.

Traditionally, the rights of control and ownership as well as the right to manage (utilize) ulayat or communal land in the 9 tribal communities or 12 indigenous people territories in Jayapura cannot be separated. Because it is a unity among the indigenous people of the Jayapura district, its existence has been recognized namely ulayat rights or communal right over ulayat land. The ulayat rights or communal rights over ulayat land traditionally highly respected and defended by 9 tribes of indigenous people on 12 indigenous areas of Jayapura who own them and other indigenous groups around their owner. The evidence that 9 tribes of the indigenous people of Jayapura district highly respected their culture and customary law, as well as their ulayat or communal rights to their ulayat land. This is shown from the sanctions used to protect the boundaries of customary territory rights or customary/communal rights to the land including natural resources contained therein.

On the other side, the cases which obtained through preliminary studies through qualitative observations and interview in the field by the research team of PT. PPMA Jayapura has identified 12 (twelve) areas of the indigenous people of Jayapura by pointing out that one that causes the problem that faced by the indigenous people of Jayapura was "the change of land status from social value to economic value in the last decade in today's development". So that it affects the socio-culture, political and economic structure, and law in communal life (social solidarity) shifts values into individual life (individualism)

At the same time, the state or the incompleteness of legal rules which accommodate and regulate the aspects of control and ownership over the ulayat land which are inherited collectively by tribes, clans/marga/keret/faam, and nuclear families in the form of ulayat or communal land by 9 tribes of indigenous people in 12 (twelve) indigenous people territories which is built on the basis of collectivity, tends to be oriented on individualism and has not provided a place for the regulation of the rights of ulayat land which is based on the conception of culture, law, and customary law that develop the basis of collectivity. This difficulty is further exacerbated by legal pluralism and/or the diversity of legal systems (state law, customary law, religious law, and other habits), pluralism culture includes : social and organization structure as well as the basic structure of the traditional economies that underlies control and ownership and utilization of ulayat or communal land in 12 (twelve) areas of indigenous people territories in Jayapura.

With the existence of difficulties in regulating the ulayat or communal land as mentioned above, which are caused by legal and cultural orientations that exist between customary law, religious law, and state law on the other hand and the cultural diversity with ethnic groups, clans, keret and fam in 12 (Twelve) of territories of the indigenous people of Jayapura on the other hand, the problem faced conceptually is "a statement regarding where to start efforts to provide a place for the regulation of customary rights over customary land by and on the state law" and/or in the form of PERDA (Regional Regulations) concerning on "Recognition of Ulayat or Communal rights of 9 Tribes of the Indigenous Law Community of Jayapura". In order to implement sustainable development for the welfare and justice of 9 indigenous peoples in 12 (twelve) areas of the indigenous people of Jayapura district, the philosophy of the Papua Special Autonomy Law is to take sides, protect, and empowering.

With regard to the overall description above, the social legal research approach used based on the emic and ethical approach which Is an alternative to understanding "The Position of Ulayat Rights and Communal Rights Based on Knowledge and Kinship System in the Sentani Indigenous People of Jayapura", in an effort identify the knowledge of 9 ethnic legal communities customs and kindship system and their

The Legal Standing of Ulayat Rights and Communal Rights of a Land Based on Knowledge and Kindship of Community System of the Sentani

Customary Law in Jayapura Regency, Papua 
legal implications due to differences in the concepts of customary law communities, government (bureaucracy), and laws in the implementation level.

\section{Method}

The juridical empirical methodology with descriptive analysis and ethnography law in emik and ethically. The data and information obtained from literature, laws and regulation, the result of studies and result of field observations by technical team, structured and systematically analyzed, regarding on the material of the data or legal material of secondary law (laws and regulation) and primary law (anthropology social reality) from SKPD regarding on Jayapura and 9 tribes of customary law community of Jayapura with 12 Sub areas on the customary area of Tabi and 4 development areas.

Social legal approach and emic and ethical approach that is responsive and based on local wisdom to the object of research study on "The Position of Ulayat Rights and Communal Rights of Customary Law Communities" in 12 (twelve) indigenous people areas and 4 (four) development areas of Jayapura

Research Location : in 9 tribes of indigenous peoples in 12 (twelve) indigenous peoples' territories in 4 (four) development areas of Jayapura Regency: randomly identified representatives of 9 indigenous tribes, namely: 1) Sentani Buyakha, 2) Moy, 3) Moy, 4) Tepra-Yewana Yosu, 5) Yokari, 6) Djouwwary, 7) Imbi Numbay, 8) Oktim, and 9) Demutru and Elseng represent 12 customary areas as follows : (1) Indigenous People of Kemtuk, (2) Indigenous People of Mooy, (3) Indigenous People of Ormu, (4) Indigenous People of Orya, (5) Indigenous People of Sentani, (6) Indigenous People of Souwari (7) Indigenous People of Tepera, (8) Indigenous People of Yokari, (9) Indigenous People of Namblong, (10) Indigenous People of Yewena, (11) Indigenous People of Klesi, and (12) Indigenous People of Yafsi Kaureh (Orya). From 12 (Twelve) areas of customary law community reside clans with ulayat or communal rights to ulayat land and individual rights based on the genealogy of their respective customary territories. Meanwhile, the 4 development areas of Jayapura are based on regional characteristics, socio-culture similarities, availability of natural resource and the distribution of human resources. The following four development areas in Jayapura, first development area which covers the Dafonsoro area, the area includes four district namely East sentani, Sentani, Ebungfauw and Waibu District. Second development areas, namely the coastal area of Tanah Merah Bay, which area included five district namely Raveni Rara District, Depapre, West Sentani, Yokari, and Demta District. Third development areas are the Grime area, which covers six districts, namely Kemtuk District, Kemtuk Gresi, Gresi Selatan, Nimboran, Nimbokrang, and Namblong District. Fourth development areas, namely the Nawa area, cover four districts, namely the Unurum Guay District, Yapsi, Kaureh, and Airu District.

Informant. The informant gave a data, which divided into three groups. First groups, are the informant consist of individual people which have a good knowledge and related with the structure of social organization also the customary law with the living aspect of Jayapura people. Second group, are informant which giving a data related with the practice of ownership and utilization of natural resource on the land, forest, kinship, economics, and politics organization which reflected on the social institutions (customary law institutions). Third groups are informant which give a data related to the actual cases about conflict or dispute on 9 tribes on the 12 areas of indigenous people of Jayapura, relating with 4 development areas of Jayapura

Population and Sample, Population are every adults (above 17 years old) which fused on the circle of 9 tribes in 12 areas. Sample Areas, 9 tribes from 12 sub area of customary community of Jayapura first development areas (1).

Data Analysis, qualitative with three (3) concurrent workflow, namely (1) data reduction; (2) data presentation; (3) drawing conclusions (verification).

\section{Result and Discussion}

The essence of ulayat rights and communal rights over the land of indigenous people of Jayapura are based on the knowledge and the mythology principal, kinship system (origin/genealogy and customary 
territorial) and customs (customary institution/customary government) with prioritize the view of 9 tribe of 12 sub-area of customary law community on the Tabi areas and 4 development areas at Jayapura.

\section{Ulayat Rights and Communal Rights Over the Land Based on the Indigenous People of Sentani, Jayapura Knowledge.}

Basically, the knowledge which identified from various informant, qualitatively from nine tribes: : 1) Sentani Buyakha, 2) Moy, 3) Moy, 4) Tepra-Yewana Yosu, 5) Yokari, 6) Djouwwary, 7) Imbi Numbay, 8) Oktim, dan 9) Demutru and Elseng, with twelve areas of indigenous people at Jayapura, which are : (1) Indigenous People of Kemtuk, (2) Indigenous People of Mooy, (3) Indigenous People of Ormu, (4) Indigenous People of Orya, (5) Indigenous People of Sentani, (6) Indigenous People of Souwari (7) Indigenous People of Tepera, (8) Indigenous People of Yokari, (9) Indigenous People of Namblong, (10) Indigenous People of Yewena, (11) Indigenous People of Klesi, and (12) Indigenous People of Yafsi Kaureh (Orya), according to the indigenous knowledge of the people on the control and ownership rights or communal rights over the land, both individual land or common land of indigenous people, in four administration development areas at Jayapura is having the same position over the ulayat rights and communal rights of the land from the legal subject view, legal object, validity (in and out), characteristics, therefore in the implementation level have difficulty on determine the borders of the ulayat and communal rights over the land based on the social structure which is kinship system on the 9 indigenous people from 12 indigenous areas above, on the 3 administration development areas of Jayapura. But, from the information gathered from various informant, ulayat and communal rights are the same normatively, while empirically in they are different at the level of the structure of the indigenous people of Jayapura, which is kinship system and customary institution known as the keondoafian or ondofolo leadership system. It means that ulayat rights which held by ondofolo on the tribe level are public rights in which there are also private right if the clan from ondoafi/ondofolo are included. Meanwhile, the communal rights are held by ondoafi/ondofolo in the clan level as a common rights of the clan and individual rights is not a common rights of the tribe. Therefore, from the study of culture and law has identified the ulayat rights or communal rights over the land have its own border based on the kinship system in accordance with the culture value or indigenous regulation on the customary law and state law, in 9 tribes of indigenous people on 12 customary areas at Jayapura. As stated above from the point of view of 9 tribes toward the ulayat and communal rights over the land based on the kinship and indigenous institution in the implementation level on the tribe level have the same position, while in the clan level both having a different position.

Therefore, it can be qualitatively described that the ulayat and communal rights over the land from the view of 9 tribes on the 12 sub areas of customary law communities of Jayapura from the aspect of culture and law.

\section{1) Ulayat and Communal Rights over the Land from the View of Culture}

The study about ulayat and communal rights problem over the land intensively still limited which described from the view of culture or law about both concept same or different on its implementation in both indigenous people on 5 indigenous areas at Papua Province. If it's minimized into 9 tribes with 12 indigenous areas that spread on 4 administrative development areas of Jayapura in the form of ethnography legal data over the customary land or ulayat/communal land, holistically or comprehensively still not recorded well, which make it difficult to obtain information on the views of the 9 tribes of indigenous people toward the ulayat and communal rights are the same or different from the aspects of the subject, object, characteristics, power to apply in or out from the aspect of culture and customary law.

From the view of 9 tribes of customary community with 12 customary areas on 4 administration development areas of Jayapura, normatively and empirically has described that the ulayat and communal rights are more into the dimension of culture and law. the study on culture dimension of the land basically shown the existence of land on various dimensions of 9 tribes life of Jayapura on Indonesia, from the past and now with the change of culture, community structure especially 9 tribes of customary community with the practice of politic domain control and utilization of land from the regional government 
(bureaucrat/OPD) of Jayapura and businessman/company public or private, which interpreted the concept of Ulayat and communal rights is the same normatively according to the political aspects without seeing the concept of the rights from 9 tribes of the customary community of Jayapura, which hold on to culture and customary law. Hence, a conflict sometimes happened in the level of implementation. As for example the former land from Netherland (such as plantation), Transmigrant land, Palm oil Land, which on the 12 customary areas and 4 administrative areas of development at Jayapura.

The view from 9 tribes of the people of Jayapura over the position of communal and ulayat rights of the land based on the culture namely birth right based on the social status in the social structure (kinship system and customary institution), where on 9 indigenous people on the 12 customary areas are on the customary areas of Tabi, which are on the Melanesia race as emphasized on the study by Erari on his book called "Tanah Kita, Hidup Kira; Pendekatan Budaya Melanesia Dalam Rangka Krisis Ekologi Global”. Erari Studies ${ }^{5}$ about the perspective of Melanesia people that a land is not just a thing without a spirit. But land is a component of the spiritual dimension so that all dimensions of human life are centered on the ground. Based on the problem arises from how the relationship between the domain of state power which are universalistic and the fragmentation of rules (legal pluralism) between customary law and state regulations which are often contradictory in efforts to organize and managing land for development purposes. Therefore, the contradiction from several studies on the context of cultre and law of the ulayat land are an important part to complete the study above, especially toward the indigenous people of Papua which has various social structural and values change on the land structure. Thus, a complete understanding of the existend of ulayat land and individual rights required an understanding of the pluralistic structure of Customary Community of Papua based on the characteristics of cultural ecology. Therefore, an understanding of the social structure is closely related to the structure of ownership rights and control and utilization of land (ulayat land). According to Geertz ${ }^{6}$ (1983) stated that the structure of the land ownership is the specific form from the pattern of social and just itself on the institution symbol that are difficult. As for example, J.R Mansoben divided into four type of traditional leader typology in the land of Papua which are 1) Big-man type on the people of Dani, Dama, Nduga, Mee, and Amugame in the areas of the Western Central and Central Mountains. 2) Tribal Chief/clan (ondoafi) in the people of Sentani, Kemtuk, Genyem, Namblong, Tepera and Ormu (Jayapura). 3) King type on the people of Fak-Fak and Raja Ampat Island (sorong). 4) mixture type on the people of Wandamen, Waropen and Biak Numfor. ${ }^{7}$ This four type of leadership type are very related to their position (status and role) on the leadership system, ownership, and utilization of ulayat land also giving an indigenous decision for the change on the status quo of the ulayat land.

Suparlan ${ }^{8}$ described that the right of communal land arrangement sometimes handed over to the head of the clan. If someday the land was converted (sold) then the head of the clan has to be responsible for it. But, doesn't have its own authority to sell it but need to be discussed together with the clan. While the Hetharia Study ${ }^{9}$, on the people of Skou (Jayapura) also shows that the authority of Harsory (tribe head) very central in structuring, distributing, releasing and resolving land conflicts (disputes) in their customary territories. It also described on Reumi studies ${ }^{10}$, on the indigenous people of Nimboran where the authority of Iram was reflected with the existence of traditional executive, legislative, and judicial institution on the structure of customs leadership (iram) which very central on controlling the community life dimension in the field of socio-culture, economics, politics, law for their people included the pattern of control, ownership, and utilization of ulayat land, including for the interest and needed of sustainable development. Therefore, universally the relation between human and ground always related with how human behave to

\footnotetext{
${ }^{5}$ Karel,P. E., (1997). Tanah Kita, Hidup Kita; Pendekatan Budaya Melanesia Dalam Rangka Krisis Ekologi Global. Prisma. Jakarta.

${ }^{6}$ Clifford, G. (1983). Agricultural Involution; The Processed of Ecological Change in Indonesia. University of California Press. Berkeley.

${ }^{7}$ Mansoben, J.R., Op. Cit.

${ }^{8}$ Suparlan, Op. Cit. 1991

${ }^{9}$ Hetharia, M., (1991). Pembebasan Tanah Adat Untuk Pelaksanaan Pembangunan Fisik di Kec. Abepura, Khususnya di Wilayah Tanah Adat Masyarakat Nafri. Laporan Penelitian FH-UNCEN.

${ }^{10}$ Frans, R. (2000). Peranan Pranata Adat Dalam Penyelesaian Pembebasan Tanah Adat Pada Masyarakat Adat Nimboran di Jayapura. Laporan Penelitian.
}

The Legal Standing of Ulayat Rights and Communal Rights of a Land Based on Knowledge and Kindship of Community System of the Sentani Customary Law in Jayapura Regency, Papua 
the land as part which cannot be separated from life of indigenous people. Then on the other study from Reumi ${ }^{11}$, on the Amungme tribe is centrally in the customary leadership known as Menagawan based on the kinship structure focused to the moety which are mom and magai that the control, ownership, utilization of the ulayat land held by the tribe, clan, and nuclear family in one legal alliance of customary law areas. While other study from Reumi for Kamoro tribe, the leadership of the customs known as Weayaiku, where the ulayat land are controlled based on the taparu-taparu principle from the clans in accordance with the social structure or institution and kinship system. ${ }^{12}$

Therefore, there are five main dimensions of a land which taken from the description above which are 1) a land as the culture identity, 2) land as a part of social structure, 3) land as the economy source, 4) land as the political phenomenon, and 5) land as the source of conflict (dispute), which stick to the life of indigenous people of Amungme tribe as well as Kamoro tribe.

So, the ethnography studies which are showed above, basically showing that the ulayat and communal rights over the land with the control system and utilization of a land which dominated from several aspect such as history, methodology, social structure, genealogy and ritual, because of a land was symbolized as phenomena of sacred value and not mere economics.

2) Ulayat Rights Over the Land on the Legal Aspect.

The right of land control on the juridical knowledge is the surface of the earth. Meanwhile, land rights are rights to a certain part of the earth's surface, which has two dimensions with length and width. The land given to and owned by a person with a rights which provided by the basic agrarian law (UUPA) is to used or utilize. The gave and owned of a land with their rights would be meaningless if its utilization was limited only to the land as the surface of earth, but also the part of earth beneath, and water and space above it. Therefore, what is owned by the right to the land given, is the land in the sense of certain part of the earth surface. Hence, the right holder may only use it within reasonable limits. ${ }^{13}$

\section{3) The Rights of State to Control}

the delegation of authority for the Indonesian people was carried out at the time of preparation of the 1945 Constitution which are Article 33 Paragraph (3) and Paragraph (4) of the 1945 Constitution (fourth amendments), indicating that the rights to control of a state are a legal relationship between the state and land in the entire territory of Indonesia, including a lands which not or has not been or has been controlled with individual rights. While which are not allowed by the Basic Law of Agrarian are the land are directly controlled by the state (Article 37, 41, 43, and 49) for the unity of the national economy (see Article 2 of Basic Agrarian Law)

\section{4) Ulayat Rights of Indigenous People}

Ulayat rights is an authorities and obligations of a customary law which related with the land located within the territory. The authorities and obligations which are included on the civil law, with the existence of elements of joint ownership of the land and some are included in the public law, namely the authority to manage, regulate, and maintain and implementing customary rights from the customary law community. Foreigners involved in using the land should obtained a permission from their customary rulers.

Keep in mind that the provision on Article 1 and 2 of Basic Agrarian Law about the implementation of Ulayat rights and other similar rights from the customary communities as long according to them still exist, it must be in such a way that it is in accordance with the national and state interest which based on

\footnotetext{
${ }^{11}$ Frans, R., (2004). Situasi Pluralisme Hukum dan Penyelesaian Sengketa (Suatu Kajian Antropologi Hukum). Jurnal Antropologi Papua. Vol II (6).

${ }^{12}$ Reumi, F., et. all. (1999). Hukum Adat Suku Amungme dan Kamoro di Timija Irian Jaya. PT. Freeport Indonesia. Tembagapura. ${ }^{13}$ Sihombing,I,(2005).Segi-segi Hukum Tanah Nasional Dalam Pengadaan Tanah Untuk Pembangunan.Universitas Trisakti. Jakarta.
}

The Legal Standing of Ulayat Rights and Communal Rights of a Land Based on Knowledge and Kindship of Community System of the Sentani Customary Law in Jayapura Regency, Papua 
national unity and mut not conflicted with other higher laws and regulations. From the Article 3 of Basic Agrarian Law can be seen, that the existence of ulayat rights is recognize as long in accordance in reality the right still exists. The Basic Agrarian Law and our national land law do not abolish the ulayat rights, but neither will they regulate them. Regulating customary rights can result in weakening their existence. Whereas the development of society shows a tendency to abolish customary rights through a natural process, namely by strengthening individual rights in the customary law community concerned. ${ }^{14}$

\section{5) Ulayat Righs over the Land}

Ulayat rights is the main rights on the customary law union of Indonesia or customary communities over the land (Van Vollenhoven, an expert from Netherland which write many studies of Indonesia tribe culture) stated that the ulayat rights or on Dutch known as Beschikings Recht. According to Eddy Ruchijat ${ }^{15}$ ulayat rights is a village rights according to customary law and authority to control the land on the region for the interest of their members or for the interest of foreign people with paying the loss to the village. In this case, the village will intervene with the land clearing or intervene with the cases happened on the village which are not settled.

The position of customary law union with land has a very close relationship, religious communalistic, this made the union of customary law community have their own right to utilize the land with using the land yield and animal hunting, open a farm, and those thing known as ulayat rights.

According to PMNA/KBPN No. 5 of 1999, ulayat rights are "an authority which according to customary law owned by certain customary law communities by a certain areas which are the living environment of their people to utilize the natural resource including land and those area for the sustainable life and the life which arise from the natural and inner relationship, hereditary, and unbroken between the customary communities of the related areas". And then on its development the Minister of Agrarian and Spatial Planning Regulations/Head of State Land Agency issued Regulation No. 9 of 2015 concerning on Procedures for Determining Communal Rights to Land, which valid for a year then revoked by the Minister of Agrarian and Spatial Planning Regulations/Head of State Land Agency No. 10 of 2016 concerning of Procedures for Determining Communal Rights. Until this day, there is no strict regulation which state about the term or the concept of communal rights with its ulayat rights from the side of legal, legal subject, characteristics and the power applied are the same. Another important things are how with the legal status of regional regulation which use the name of ulayat rights then change into regional regulation of communal rights, also with the issued of Minister of Agrarian and Spatial Planning Regulations No. 10 of 2016 which revoke the Minister of Agrarian and Spatial Planning Regulation No. 5 of 1999 concerning the Procedure of Ulayat Rights settlement Problems. All those issues still being debatable in the academic world, bureaucracy, and company that still finding the legal certainty and/or finding regulations about land with neutral law to facing the pluralism law situation over the related policy.

6) Ulayat Rights and Communal Rights over the Customary Land on the Kinship System of Sentani Indigenous People at Jayapura.

Basically, the kinship law is a relationship which order of relation is influenced by customary kinship law according to the structure of their respective communities. The kinship and kinship relationship are not only limited to the existence of blood ties and marriage, but also occur due to a good relationship which is a customary relationship in the form of adoption of children or relatives or recognition. Between members of one family and another, legal relations and cooperation are established to help each other on the daily life. The legal relationship applies in accordance with the customary law and the indigenous peoples concerned. The scope of customary kinship law including personal position, engagement, legal

\footnotetext{
${ }^{14}$ Sihombing, I. E., Ibid.

${ }^{15}$ Ruchijat, E., Op. Cit.

The Legal Standing of Ulayat Rights and Communal Rights of a Land Based on Knowledge and Kindship of Community System of the Sentani Customary Law in Jayapura Regency, Papua 
marriage, husband and wife position, child relationship with parents, child and relative relationship, childcare and divorce.

\section{a. Customary Land on the Indigenous People of Jayapura}

The indigenous people of Jayapura consist of 9 tribes or tribal council: 1) Sentani Buyakha, 2) Moy, 3) Moy, 4) Tepra-Yewana Yosu, 5) Yokari, 6) Djouwwary, 7) Imbi Numbay, 8) Oktim, and 9) Demutru and Elseng, on 12 areas of customary people namely: 1) Indigenous People of Kemtuk, (2). Indigenous People of Mooy,(3). Indigenous People of Ormu, (4). Indigenous People of Orya, and (5). Indigenous People of Sentani, (6). Indigenous People of Souwari, (7) Indigenous People of Tepera, (8 Indigenous People of Namblong, (9) Indigenous People of Yewena, (10) Indigenous People of klesi, (11). Indigenous People of Yokari, (12) Indigenous People of Yafsi Kaureh (Orya), claimed the resource of customary land known as land natural resource in the indigenous area of Tabi. The source of customary land also divided into four development administration areas at Jayapura, authorized on the customary systems known as collective rights/communal clan from the tribe in 9 customary community at Jayapura. to understand, it can be described as follows: that customary land resource that are controlled collectively/communally, either as ethnic group or as clan are known as internal divisions between clan members with their respective on ondofolo leadership. In addition to the internal division of customary land resource, it is also known that the distribution of customary land resource externally with other clans and even other tribes, is based on the history of origin and marriage within 9 ethnic groups of the indigenous people of Jayapura in a sustainable manner. The other clan stay in the source of land resource owned by certain clan as "new people" in the environment of certain customary communities. Knows as new people because they are on the claim rights to the customary land resource with the following characteristics: a) temporarily, b) knowing his customary land resource elsewhere, c) opening for him the opportunity to return to the customary land resource his birthright at any time, and d) they always aware or advised that he is not the owner of the clairvoyant rights over the customary land resource related.

From the explanation above it can be seen that the detail through reading the ownership diagram, control, and utilization of land resources in the 9 tribes of Tabi customary communities, according to culture and customary law. The aim is simple, so all the parties including 9 customary communities of Jayapura know better about the customary law and the 9 customary communities culture pattern in Tabi, which are inherited by the ancestor of each indigenous people of Jayapura which are applies today in the context kinship and ownership, control and utilization of Tabi customary land.

Therefore, we can describe the culture pattern and customary law of 9 tribe of Jayapura holistically and comprehensively on the perspective of control and ownership of customary land ownership which will be the "culture fence (pagar budaya)" which giving a guarantee that a people or a group are the owner or not the owner. According to the result of two researcher which are 1) Frans Reumi from the Faculty of Law of Cendrawasih University seen the function of kinship law as the approach model to proving a legal certainty in cases of customary land disputes today; 2) Anderias Goo, Majoring in Anthropology Faculty of Social and Political Sciences of Cendrawasih University gave an explanation about the kinship system and ulayaat rights over the customary land in the field of inheritance based on the marriage and kinship system over the customary land.

A. Marriage Culture

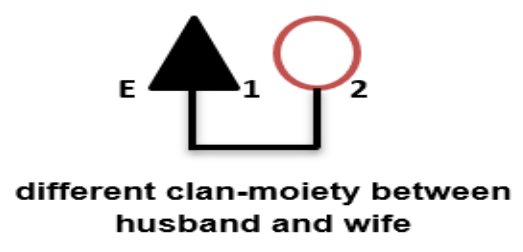

Fig. 1 The Rule of Marriage

The Legal Standing of Ulayat Rights and Communal Rights of a Land Based on Knowledge and Kindship of Community System of the Sentani 
According to the view of 9 tribe of indigenous people of Jayapura concerning about rights and obligation about inheritance of customary land resource following the figure above then it can be described as follows:

1) When a man [1] would like to propose a woman as his wife [2] then thing should be obeyed are:

a. Ensure that the woman [2] have a different clan with the man [1]. The clan difference is important on the 9 tribes of indigenous people of Jayapura myth as stated above.

b. The differentiation of clan in the environment of 9 tribes of indigenous people of Jayapura pointed on the clan difference, as for example the man of the indigenous clan should find a woman outside their clan on the one tribe or outside their tribe or even across the tribes.

i. Ego Children Generation are prohibited to married with the mother clan and grandmother clan [grandmother from mother] which still have direct blood relation from one generation.

ii. When the total of dowry has been paid then the woman will following the man to the father houses or in the man houses.

B. The Culture of Giving a Clan Name Including the Rights and Obligations

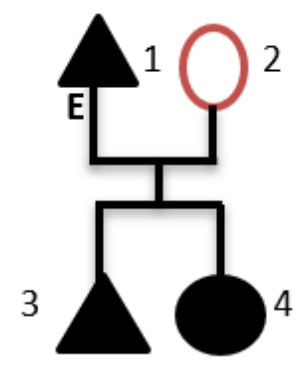

\section{son and daughter who were born to join the father's clan}

Fig. 2 The rules on granting a clan, rights and obligation which attached to it.

According to 9 tribes of indigenous people of Jayapura about rights and obligation on the inheritance system of customary land resource following the figure above, then it can be described as follows:

1) After the man [1] and woman [2] starting living together as a husband and wife, then the wife [2] supposed to be pregnant and giving birth to a biological son [3] and daughter [4]

2) The children [3\&4] will be given the same name of the man clan name (following the father, Ego) [1] including all other rights and obligations.

3) What rights and obligations are obtained from the name of the clan as rights and obligations for the children? The following describes the rights and obligations obtained by children [ $3 \& 4]$ in the context of using the name of their clan.

a. Rights:

i. The biological son [3] and daughter [4] have a right to use their father clan name

ii. The biological son [3] and daughter [4] have a right to build a relation-communication with father [1] and mother [3] relations.

iii. The biological son [3] and daughter [4] have a right to be cared by parents [1\&2] from the natural resources owned by the father, Ego [1]

iv. Natural resources owned by father [1] will only inherited to the biological son [3] while biological daughter [4] not because the daughter [4] will married and living in their husband relatives, while biological son [3] will live in the house and his father [1] natural land resource. 
v. Biological daughter [4] can come to farming in her father customary land [1] or her brother [3] if in her place where she's married is infertile and lack of food or experiencing major disaster.

b. Obligations:

i. Biological son [3] and daughter [4] feel the obligation to use the clans name to differentiate with others, with others clan and other moiety which serve as the differentiate medium of identification characteristics.

ii. Biological son [3] and daughter [4] feel physically and economically responsible for various socio-economy faced by the same clan so that various socio-economic events related to their clan are understood as events involving themselves as well. As a result, it always participating on the process related to the intended event.

iii. Biological son [3] and daughter [4] have an obligation to defend their clan for the safety of customary land resource which owned by the related clan

iv. The biological son has an obligation to inherited the customary land resource to all the biological son which born from the marriage with his wife, because the biological son is the heir of the rights and obligations for the next generations with related with the customary land source from each 9 tribe of indigenous people of Jayapura

v. The son is not required to transfer the family customary land, clan customary land or customary land of 9 tribe of indigenous people to other parties who are not clan or tribes without rational reasons in the perspective of 9 tribe of indigenous people in Jayapura.

C. The Culture of Sharing Customary Land Resource for the Biological Son from 9 Tribes of the Indigenous People of Jayapura

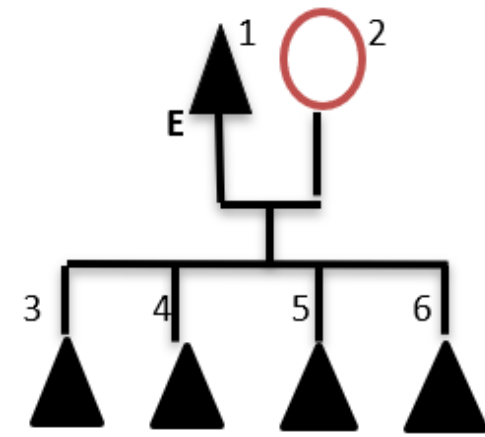

The pattern of inheritance of land

resources in many biological son

Fig. 3 Rules for the distribution of land resources among the biological son

From the view of 9 tribes of indigenous people of Jayapura concerning on rights and obligation on the inheritance of customary land system following the figures above then it can be described as follows:

1) The son $[3,4,5,6]$ from one batih family is distributed based on justice principle.

2) Every son $[3,4,5,6]$ has given the same rights to inheritance and having the clan customary land on the tribe which inherited by their father, Ego [1].

3) Inheritance of rights to the biological son isn't based on the priority rights primogeniture, rights which given are prioritized for biological firstborn child.

4) Parents [1] from the biological son $[3,4,5,6]$ held a full authority to determined which son will be managing the resource of customary resource and which will be working on it.

5) However, for common land resources belonging to the clan, such as villages, cemeteries, and places to look for pandan fruit are left to be managed jointly by clan members from each of the 9 tribes of the Jayapura indigenous people. 
D. The Cultural Inheritance of Land Resource to the Biological Sons of Man and From the Biological Sons to the Son of the Next Generation of Man.



Fig. 4 The rules of inheritance of land resources to children from male siblings who give birth to daughters and biological sons.

According to the 9 tribes of Jayapura indigenous people about inheritance of customary land to many sons from the man who already married then the pattern of the culture according to the customary law as follow:

1) Every sons $[3,5,7,9]$ have a full obligation to be the true heir of every customary land resource owned by their biological father, Ego [1].

2) When the son $[3,5,7,9]$ have married with their wife $[4,6,8,10]$ then the inherited rights will be given to every children which born from the marriage between husband and wife.

3 ) If the biological son of the man [3, 5, 7, 9] Ego, which already married are give a born to only daughter $[11,12,13,14,17,18]$ then the daughters $[11,12,13,14,17,18]$ didn't have any right to the customary land resource to be claimed as the person who have rights to be the heir.

4) If only one of the male siblings [7] Ego, only have a biological sons [15 \& 16] which are successfully born, then the people who are fully entitled to become heirs are the two brothers [15 \& 16]

5) Both brothers [15 \& 16] have a rights to inherit the clan land resources, including the land resource which supposed to be rights of the children $[11,12,13,14,17,18]$ their siblings $[3,5,9]$ because the daughters $[11,12,13,14,17,18]$ is not allowed to be the inheritor of customary land resources belonging to his family or clan.

6) The culture of 9 tribe of Jayapura Indigenous People regulates that the daughters $[11,12,13,14,17$, 18] will be married with a guy from other clan and they will live from the resource of other clan customary land which she will married to, because the patrilinear marriage system.

7) Therefore, the point of view of 9 tribe of Jayapura Indigenous People which then to maintain the stability of socio-economy on 9 tribes of the Jayapura indigenous people since their first ancestor.

E. Culture of Inheritance of Land Resource to the Sister Son

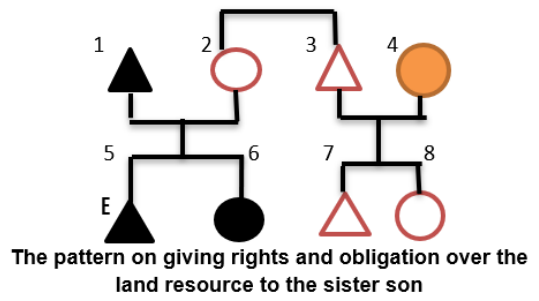

Fig. 5 Rules of inheritance of land resource from mother brother to ego which known as sister son 
According to 9 tribe of Jayapura indigenous people about rights and obligations on inheriting the land resource following figures above then it could be described as follows:

1) Inheritance of the land resource by mother brother [3] to Ego [5] as a child from the sister son cannot be allowed or known as taboo or forbid.

2) The argument is simple, Ego [5] and mother brother [3] from different clan and moiety, mother brother doesn't have obligation to inherit the land resource to the sister son.

3) Mother clan [2] and mother brother [3] is the same, but both clan of brother and sisters [2 \& 3] is in definitive different with Ego.

4) Therefore, Ego [5] can only inherited a land resource from father [1] with the same clan as Ego [5]

5) So, mother brother [3] giving a right of inherit to her biological son [3] which are a man, while her biological daughter from mother brother [8] also didn't get inheritance right of the land resource.

6) Except mother brother [3] giving Ego [5] certain rights and obligation on the other aspects such as psychological, cultural education, religious, and others.

F. Inheritance Culture of Land Resource to Affinal Kin Relatives

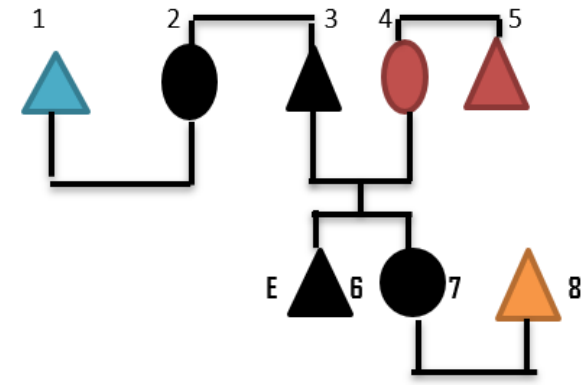

Pattern on giving rights and obligation over the land resource to affinal kin

Fig. 6 Rules on land resource inheritance to giving and obtaining rights and obligation of land resource for relative because of affinal kin

According to the view of 9 tribes of Jayapura indigenous people about the rights and obligation on the land resource inheritance following the figure above, it can be described as follows:

1) The giving pattern or obtained pattern of rights and obligation on the land resource owned by the clan for the affinal kin relatives such as father sister husband [1], mother brother [5], and sister husband [8] is not allowed or even prohibited.

2) Because the affinal kin relative have a different clan with Ego [6] and father [3].

3) Every clan was regulated to get rights and obligations of the customary land resource must be from their own clan, otherwise they $[1,5,8]$ also doesn't have a right to giving a land resource to the Ego [6], because Ego [6] definitively have a different clan with their affinal kin.

G. Customary Land Resource Inheritance Culture to Adopted Child

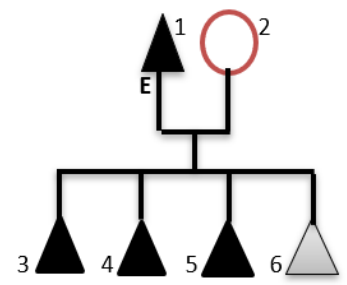

Pattern of land resource inheritance

to adopted children

Fig. 7 Rules on customary land inheritance which given to the adopted children 
According to the view of 9 tribes of Jayapura indigenous people about the rights and obligation on the land resource inheritance following the figure above, it can be described as follows:

1) The pattern of customary land resource inheritance to the biological son of Ego [3, 4, 5] with adopted children [6] is equally or fair.

2) Adopted child [6] is counted as biological child as long as he is educated and nurtured as a man from 9 tribes of Jayapura indigenous people on the Ego houses [1].

3) When adopted child has grown up then the adopted child will be given a freedom to back to :

a. Their village, and

b. Using the clan name (this condition happened when the adopted child have a proto clan which different with Ego, but if it's have the same clan with Ego then the clan name will not be changed) and

c. The rights of the land resource from their clan inheritance.

4) The adoption process happened because of compassion for the death of his parents.

5) The adoption process is temporary and only required to be carried out by the mother brother (in the section above Ego [1] is assumed to act as a mother brother), where the adopted child is clearly different from the clan with the mother brother whose clan name is the same as the mother.

6) The purpose of the process of adopting a child in the Amungme culture is to provide protection, safety, and independence that are culturally correct for Amungme tribe to the son [6] which adopted.

H. The Culture of Customary Land Inheritance to the Relatives When All Biological Son Died Before Married or Having a Family

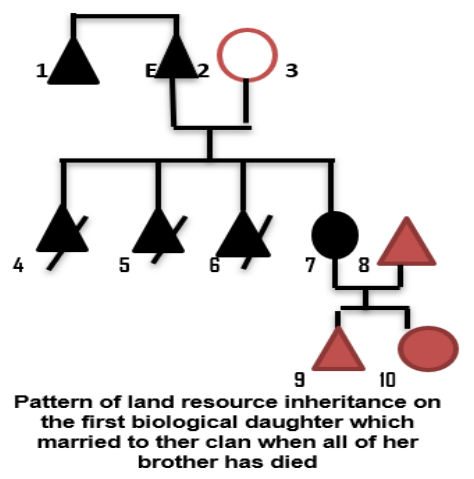

Fig. 8 Rules of customary land inheritance when all of biological son has died before having a family and the remaining is a daughter and then the daughter is marrying

According to the view of 9 tribes of Jayapura indigenous people about the rights and obligation on the land resource inheritance following the figure above, it can be described as follows:

1) The pattern of land resource inheritance to the daughter of Ego [7] when all her brothers [4, 5, 6] has died before having a generation then the daughter [7] and her husband [8] or even her child [10] from the daughter cannot inherit the ownership of the customary land owned by Ego [2] which her father from sister [7]

2) Because the daughter [7] should be married to other clan [8], giving birth to a children [10 \& 11] from other clan and got a right of a customary land resource to managing it from her husband clan [8]

3) Therefore, father customary land resource. Ego [2] will be taken by father brother [1], her father biological brother, or biological son of her father brother if the father isn't polygamous and has not given birth to his biological son. Because there is an opportunity, where the Ego [2] provide an opportunity to perform a polygamy with a certain ne wife in order to obtain or giving birth to a biological son which can be the inheritor of property rights and power rights of the resource of his ancestral land. 
I. Culture of Land Resource Inheritance to the Biological Son on the Sororat Marriage

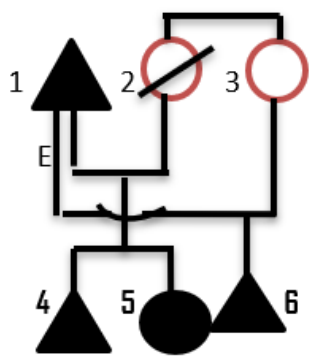

Pattern of sororat wedding and the customary

land resource inheritance

Fig. 9 Rules on Customary land resource inheritance when his wife died after giving a birth of a biological son and daughter, then the biological sister married with a widower from her biological sister, thus giving birth to a son as well

According to the view of 9 tribes of Jayapura indigenous people about the rights and obligation on the land resource inheritance following the figure above, it can be described as follows:

1) Before Ego [1] becomes a widower, two biological children were born to him, one a boy [4] and the other a girl [5].

2) When a father become a widower [1] and having a sororat wedding [3], then giving a birth to a son [6] then the pattern will be followed is, both for the first-born son [4] from first wife [2] or second born son [6] from second wife [3] have the same rights and obligation and equivalent with both son [4 \& 6] from both wife sisters [2, 3] which married by Ego, Father [1]

3) So, for the father or Ego [1] and biological son [6] from the wife of sororat wedding [3] seen as his own son

4) The fathers' job on inherited the land resource to both son [4 \& 6] has equal or equal cultural value in terms of justice or cultural equality 9 tribes of the indigenous peoples of Jayapura.

J. Culture of Land Resource Inheritance to the Biological Son from the Pattern of Levirat Wedding

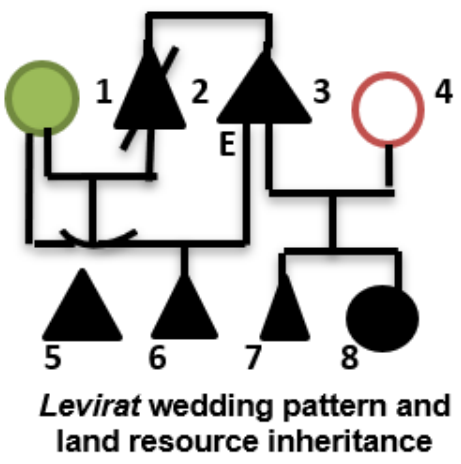

Fig. 10 Rules when a biological brothers died, the widow's wife of her deceased male sibling marries her male sibling who is still alive and then the widowed woman gives birth to her biological son and daughter.

According to the view of 9 tribes of Jayapura indigenous people about the rights and obligation on the land resource inheritance following the figure above, it can be described as follows: 
1)Before bother [2] died, he [2] already giving a birth to a son [5]. This child has an inheritance right of the land resource from his father [2]

2)The brother wife [1] held a sororat wedding with her husband brother [3]

3)If the brother [2] died when her biological son [5] still a child then the adoption rights will be taken by Ego [3] by marrying the wife [1] of his brother [2]

4)The wedding between the widow of his brother [1] and Ego [3] giving a birth to a biological son [6]

5)Then for Ego [3] born a son [7] as a result of his wedding with his wife [4]

6)The land resource inheritance pattern to their child [6 \& 7] from the Ego [3], as brother child [5] inherit a land from his father which already died [2]

7)So, Ego [3] and brother [2] giving a rights and obligation of the land resource to each child equally and fair. Because Ego [3] and brother [2] is a biological family from the same clan and moiet on claiming the land resource of their ancestor.

K. Culture of Land Resource Inheritance to the Biological Son from Polygamy Wedding

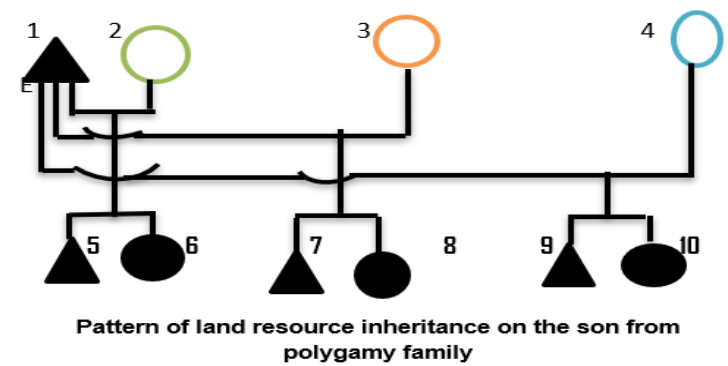

Fig. 11 Rules on a man of 9 tribes of Jayapura indigenous people have a polygamy and the pattern of rules of land resource inheritance

According to the view of 9 tribes of Jayapura indigenous people about the rights and obligation on the land resource inheritance following the figure above, it can be described as follows:

1) A polygamy wedding is a common wedding between a man with taking several woman as his wife between 9 tribe of indigenous people also other tribe in Papua provinces.

2) Ego [1] marrying several wife [2, 3, 4]

3) The wives then giving a birth to a son $[5,7,9]$ and a daughter $[6,8,10]$

4) The sons' $[5,7,9]$ obtained a resource from customary land with the principle of equality and fairness from their father [1]

5) Therefore, all the sons' [5] are counted to obtained inheritance rights of the land resource from their father [1] on the contrary, the daughter of $E g o[6,8,10]$ will not be the heir with ownership and control rights except usage rights.

L. Culture of Land Resource Inheritance to a Biological Son When his Mother Divorced from her First Husband



Fig 12. Rules of Land resource inneritance wnen a aivorcea occurs witn first wives that have a son and father remarried and gave birth to a male biological child as well.

According to the view of 9 tribes of Jayapura indigenous people about the rights and obligation on the land resource inheritance following the figure above, it can be described as follows: 
1) The Ego [1] wedding with his wife [2] gave a birth to a son [4].

2) Then a divorced happened between $E g o$ [1] and his wife [2] because of jealously ends in divorce.

3) The divorce wedding on the 9 tribe of Jayapura indigenous people, there will be several consequence such as:

a. Divorced happened between the wives on pregnant condition then the divorced wives can marry with the new husband, but new husband should pay for the dowry to the first husband [1] and also paying the dowry to the parents of the women;

b. If the divorced happened while the wives are pregnant then the children on the womb of the divorced wives by 9 tribe of Jayapura indigenous people, considered as first husband child [1]

c. If the wives give birth to a child in her womb from the environment where her new husband lives, the child will be taken by the first husband, if there's a refusal there will be a war to prosecute the return of the child fertilized by the first husband [1]. The war condition will be change to be a peace if the child which were born by the divorced wives recognized and counted as the child of the first husband by the second husband as well as the close relatives of second husband.

4) The land inheritance by Ego [1] to the second son [4 \& 5] from both different wives obtained a rights of the land fair, equal, and cultural value of 9 tribes of Jayapura indigenous people which are appreciate and respecting between the ownership of relatives and or genealogical relatives.

\section{Culture of Customary Land Inheritance to the Other Clan Which Stay on the Ego Village}

According to the view of 9 tribes of Jayapura indigenous people about the rights and obligation on the land resource inheritance following the figure above, it can be described as follows:

1) The view of 9 tribe of Jayapura indigenous people about the pattern of inheritance of customary land from Village A - for example - owned by Clan C, at the Village A also other clan such as D and E

2) The ownership clan or the village guard is Clan F, but a new clan which lives in the village $A$ are having inheritance and ownership rights in the Village $\mathrm{X}$ and/or Village $\mathrm{Z}$ which are other territories

3) Therefore, the other clan known as new clan, newcomer clan, and/or neighbor clan. The new clan rights (newcomer, neighbor) in the Village A are just usufructuary rights, not ownership or inheritance rights. The usufructuary rights given with purpose to save the life of his inner family in order to survive. 4) While the land resource inheritance to the land resource that are birthright are sourced from the origin of village (Village $\mathrm{X}$ or $\mathrm{Z}$ ) from the related clan

5) Even though, because the new clan has the rights to use it to live, the new clan can look for firewood, gardening, and building a houses in related village.

The main argumentation on why the clan is not the owner of land resource which allowed to live in certain village are:

1) Genealogy reason, that they are relative, genetically or affinity.

2) Confederation or partnership on war in the past. on present.

Both reason which allow the form of village in 9 tribe of the Jayapura indigenous people district

While things which are the problem on this study are the need of data about a story of the clan and tribe spread, with the history and kinship system of 9 tribe of Jayapura indigenous people.

On those two aspects lies the formation of the current village pattern. To find those two things that do not ask about the distribution of the population first, but research on wars that must be done. It is in the story of the war that we will find the story of the spread. So, research on political anthropology and marriage/kinship law, inheritance law, and customary constitutional law is urgently needed. 


\section{N. Culture of Settlement of Customary Land Resource Cases.}

The dispute cases of customary land resource between 9 tribe of Jayapura indigenous people, never happened crucially and continuously as happened in others ethnic group in others continent, because there are several cultural consideration which described as much more important

a. The clan rights known by all the member of social community.

b. Even the people population from the certain clan has been extinct, the inherited resource land will be remembered by social community as owned by certain clan that have been extinct, but can be used by the relative clan which living together at the same community

c. The knowledge about ownership rights as nucleus family, as clan, and as 9 tribe of Jayapura indigenous people known as socio-economy

d. 9 tribes of Jayapura indigenous people are not opened when trying to deliver several knowledge about customary land resource which known as sacred in the level of the clan and 9 tribe of Jayapura indigenous people to the people of non-tribes of Jayapura indigenous people

e. Between 9 tribe of Jayapura indigenous people there are no conquest of customary land resource and diversion of customary land by forced and compulsion.

The dispute cases of land resource happened in the customary areas of Tabi, especially in 4 development areas of Jayapura today. 9 tribe of Jayapura indigenous people which live on the 4 development areas of Jayapura no longer recognize a land resource owned by the clan but owned by together communally, but just known about the customary land resource owned by nucleus family. Now, an Ego which are the biological child from the father brother which coming from the resource of customary land of 9 tribe of Jayapura indigenous people is not given a usufructuary rights or ownership rights over the land which control by an Ego which are their family. Because people of Jayapura have thinking and act using the culture of other state, especially on the way of thinking and the act of Malay which dominate it today. Therefore, 9 indigenous people of Jayapura who live in customary land resource think, that there is a division of district in Jayapura customary land resource, a) poor living condition and bad behavior occur in the village, Jayapura will also be happened on the customary area of Tabi; b) the behavior of not respecting and acknowledging clan/relatives committed by 0 tribe of Jayapura indigenous people who live will occur in Tabi customary area when the divisions of village occur.

\section{O. The Land Resource with its Purposes}

According to its function, the customary land resource of 9 tribe of Jayapura indigenous people is classified into two, which are private customary land resource or family/clan and tribe land resource. Private or family/clan land resource is the resource which sometimes used for a family to build a house and customary land resource for farming. While land resource for clan/public is a land resource used for common interest and for collective/communal/ulayat of all family and clan/tribe which are in the village, district, region or city of 4 development area of Jayapura which are"

1) Land resource for villagers is a land resource owned by the clan from 9 tribe of Jayapura indigenous people on the 4 certain development areas which allowed by the owner on mutual agreement. Therefore, a village were built which will be lived by a Clan Heterogeneity and one of the clan will be act as the owner of the village or the owner of the related village customary land owner.

2) A customary land cemetery is a customary land resource which approved on by the clan that a certain places will be used for cemetery for everyone who died on the related village.

3) Customary river land is a claiming pattern of river land resource based on the central point of water and the water flow owned by certain clan following by the view of 9 tribe of Jayapura indigenous people, which are 4 development areas of Tabi indigenous people, so that other river can be claimed by other clan as their river, and the river can be the border of eternal customary land resource between village, district, between customary land and administrative area, between clan and also between certain ethnic group. 
4) Mountain customary land resource or a forest is a plain or expanse with a certain bending [low, medium, high, and very high] with a knowledge of the owner, so it will be not possible to be claimed by others clan which are not the owner, except the claim from the owner which are allowed for certain mountain.

5) A sacred customary land resource is a certain areas known as placed which have a charm of high supernatural, so this areas known with two main things which are the existence of other certain important things that are strictly forbidden to do with the existence or certain things which are allowed to do.

6) The resources of the customary land of the trail are a link between a houses with others, between houses and a farm, between houses and forest land resource or mountain, house and river, houses and cemetery, and village with another village. The trail or a road for 9 tribe of Jayapura customary land is a link which are consensused in culture, that all activity should carried out through road leading to their destination in the four development areas of Jayapura.

\section{Legal Implication on the Different Perception of Indigenous People, Government (Bureaucrat), and Laws.}

\section{1) Sentani Indigenous People Perception.}

Basically, the perception of Sentani indigenous people from 9 tribe on the 12 sub customary areas over the ulayat and communal rights over the land is having the same term but only have a different position on its institution especially on kinship system. Means that the ulayat rights position held by tribe, while communal rights held by the clan and main family these day. Related with that then the implementation of ulayat rights and communal rights over the land and its resource seen as a whole including earth, water, space, and natural resource which contained in it. This perception seen based on the culture ecosystem and ecology which having a tight relation with the dependency principle. This perception having a cultural values and customary norms which centralized on the customary land as the life base power on the Sentani indigenous people from 9 tribe with 12 customary areas over the ulayat and communal rights over the land, Symbolically the customary land on their culture understood that a land is mamaku (mother) and the land is the live-giving creator (religiously). With this view from Sentani indigenous people, is fair because the private ownership rights or collective are attached on the clan and/or tribe which cannot be sold. Therefore, having a collective culture value from several interest which are : politic, economy, socio-culture, and religious which still attached to the related indigenous people.

Normatively and empirically the concept of customary land ownership of Sentani from 9 Tribe on the 12 Customary areas, have a reciprocal powers. Individual property rights become very strong, if their position in collective property rights becomes weak. If a private property rights are faced out, then the ownership rights of the partnership become very strong, then the individual property rights to customary land become weak. The ownership rights of customary land cannot be transferred in form of buy and sell of the land as adopted by Basic Agrarian Law 1960. The construction of ownership rights has been built by the ancestor of the Sentani indigenous people from 9 tribes in 12 customary land in accordance with the cultural values and customary law as the living law which believed and developed and manifested on rights of the ownership, control, and usage system over the customary land and natural resource of Sentani indigenous people.

Moreover, the perception of sentani indigenous people from 9 tribe on the 12 customary area tech us to see on the Netherland New Guinea government era, where the high officer has written the result of their own research on the report of indigenous land rights in New Guinea. It stated that, as long it is known and were an important rights which are on the family fellowship, customary genealogy-patrilinear or genealogy-matrilineal, and genealogy-territorial is a clan and others. The rights such is especially on Sentani indigenous people known as Inlandsbezitrecht. At New Guinea, this such rights known as Papua Bezitsrecht namely land rights with very strong individual characteristics. Once someone opened a land, then it will be an individual rights for a member of the indigenous community who opened it. For forest land, for every members of family which will be open it should obtain an authorization to the head of

The Legal Standing of Ulayat Rights and Communal Rights of a Land Based on Knowledge and Kindship of Community System of the Sentani 
fellowship which control an environment of a land. On the view of Sentani indigenous people, knows that land and forest which already opened and currently worked on, a land with a forest which never been opened, but still on the territory of Sentani customary community.

The existence of a research and workshop which done by YKPHM of Papua still found a views about land ownership rights of indigenous people are different with ulayat rights and other rights given by state according to Basic Agrarian Law 1960 normatively nor Minister of Agrarian and Spatial Planning Regulations/Head of State Land Agency No. 10 of 2016. According to the Sentani indigenous people, ulayat and communal rights simultaneously held by the tribe or clan is a control rights and ownership rights for individual or collectively on the tribe and clan level, because the rights of Sentani indigenous land not given by the state according to Basic Agrarian Law 1960. But the rights over land, water, customary territory space, and natural resource which contain in it has been obtained and controlled in accordance control rights and ownership rights from generation to generation with its strongest and most comprehensive based on genealogical and territorial customs. Relation between humans on the Sentani indigenous people over the land, water, and space of customs, and natural resource contain in for of legal relation which controlled with ownership rights, because it contained all cultural values system and an ideal custom norms which included politic interest, economic, socio-culture and religious as the part of ethnography portrait of Sentani indigenous people on 12 areas of Jayapura indigenous people.

\section{2) Government Perception (Bureaucrat)}

The view of almost all government officials both in the level of central government and regional government have it own political power on facing the development of ulayat land/communal land with the community or indigenous people especially on 9 Jayapura indigenous people, freely can given an interpretation about what does it mean with ulayat and communal rights are the same which controlled and hold by state in accordance with Article 33 Paragraph (3) of Constitution 1945. The official of Regional Government of Jayapura on several discussion have given an interpretation to ulayat and communal rights which the position still not clear. It means that ulayat rights as public or common rights and individual rights of customary community which held by the head of tribe or clan has been appointed on Basic Agrarian Law 1960 become ulayat rights which held by the state as an organization of the highest politic control but this view still not accepted well by the Sentani customary communities in Jayapura.

Normatively or empirically in Jayapura it can be seen that the view of regional government some of them stated that Sentani indigenous people is not the legal subject, so there's no customary wealth such as natural resource, as we know according to code of civil law which people and legal entity. In other words, the customary people of Sentani didn't have legal entity so the legal subject is not attached to them.

Thus, if there's a development project on a legal area of customary community of Sentani, then according to the principle which prioritize public interest, ulayat and communal rights of Sentani indigenous community should be customized with the public interest and cannot be contrary with the higher laws and regulation. Sentani indigenous people are simply given a recognition which are the development of public service for public interest.

The perception of government and regional government also, isn't profitable to the customary community of Sentani, but profitable to outsider (investor) to obtain land and other natural resource, because there is a collusion with the government and regional government on granting permission administratively. Hence, nationally or regionally, on several regional government officials in real they're not admitting the existence of Sentani indigenous community and ulayat/communal rights over the land. according to government and regional government, ulayat rights of indigenous people of have been elevated to state ulayat rights and cannot be think more that the regional ulayat rights or group ulayat rights or tribe/clan. Such attitude still reflected on several Sentani indigenous people at Jayapura.

The Legal Standing of Ulayat Rights and Communal Rights of a Land Based on Knowledge and Kindship of Community System of the Sentani 
The governments statement such this can very affecting the opinion of Jayapura government in giving ain interpretation to what does ulayat/communal rights mean over the ulayat land according to their perception, not from Sentani indigenous people perception which concerned with the land resource potential and other resource. The perception of government then very confusing for the indigenous people of Sentani and as if the rights of the land of Sentani customary community were determined by the related government of Jayapura at the Ulayat/Communal land of Sentani indigenous people.

\section{3) Basic Agrarian Law 1960 Perception}

According to Basic Agrarian Law 1960 about the principle of controlling the land rights clearly giving an understand that state controlling the land according to the Article 33 Paragraph (3) of Constitution 1945. That the land, water, and its resource contained therein as well as possible for the greatest prosperity of the people, this is an important mandate which adapted by Basic Agrarian Law 1960. Relating to the land rights which are not registered and controlled by the people, it is regulated on the Article 3 of Basic Agrarian Law 1960 about ulayat rights (customary rights).

In general, the ulayat rights is a rights to control which held by related indigenous people over the land, forest, and living environment. Article 3 of Basic Agrarian Law of 1960 stated that ulayat rights is “ the rights of control over a land held by customary law community - as long as it still exists and must be adapted to the interest of wider development, national unity and integrity and must not conflict with other higher laws and regulations. If there's a wide interest for development for public interest, then the customary community should adjust with the development for public interest, because seen that unity of the state cannot be destroyed by a group interest and individual. The regulation of Article 2 of Basic Agrarian Law of 1960 stated that the highest Ulayat rights held by the state will be used for the greatest prosperity of people.

Ulayat rights considered as the ownership rights of customary community, but the term is not founded on the general explanation, but on the article per article. What is meant by ulayat rights is what are in the customary library known as Beschikkingsrecht. Which is a theory about control rights over the land which explained by Van Vollenhoven that written many research about alliances of customary community in Indonesia.

According to his view, the rights over the land which held by customary communities and the members is the right to control the land, because they don't have ownership rights. This concept and view used as the definition of ulayat rights. While ulayat rights it self is adopted from Minangkabau language, means the rights to control over a land which held by the head of the tribe.

The classification of land can be seen from its legal status, there were two legal status in Indonesia, that is Not State Land which is every land that controlled by people based on the ownership rights and State Land, which are all the land, directly and indirectly controlled by state. The land which controlled by the state including a land without owner, known as Free State Land, while land which indirectly controlled by the state are Non-Free State Land.

The land which are including in the group of Non-Free State Land is a fee state land which are given to someone with cultivation rights or building rights. A free ste land which has given to the institution or instances with usufructuary rights and a land of people which the rights of the land still not converted (transferred) to the rights which recognized by laws and regulation. Based on this view, then every rights of land which recognized by the laws and regulation such as, Ownership Rights, Building Rights, Cultivation Rights, is several of land rights which given from the state to every Indonesian. This type of rights can be transferred through buy and sell and at anytime the right can be drop because it is facing with the development for common interest.

The regulation to revoke this type of rights already regulated on the Law of Revocation of Land Rights No. 20 of 1961 concerning of Revocation of Rights of Land and the Objects Over the Land as the

The Legal Standing of Ulayat Rights and Communal Rights of a Land Based on Knowledge and Kindship of Community System of the Sentani Customary Law in Jayapura Regency, Papua 
organic laws which based on the Article 18 of Basic Agrarian Law 1960 concerning on institution of revocation of right of land. this laws and regulations didn't have an executor regulation, but on behalf of government, Ministry of Internal Affairs issued a regulations with Regulation of Ministry of Internal Affairs No. 15 of 1975 concerning of Land Acquisition, then amended with President Decree No. 55 of 1993 Concerning on Land Acquisition for Development for the Common Interest.

The government themselves, have some issue on facing the land acquisition and procurement for development for common interest. This regulation placing the community rights of the land on the lowest level and weak. Therefore, the problem which more important is a discussion on land procurement for the development of common interest.

This can be confronted with the issuance of the Minister of Agrarian and Spatial Planning Regulations/Head of State Land Agency No. 10 of 2016 which did not provide a clarity about the position of ulayat and communal rights related with Article 3 of Basic Agrarian Law for the Sentani indigenous people in the implementation level of the authority on the institution of customary structure systems which in this case are kinship system between the ulayat rights/communal rights holder for the tribe and clan.

\section{4) Perception from Company}

In general, the perception of company following the perception of government (bureaucrat) and Basic Agrarian Law. Means the perception of company toward the Sentani customary community which identical with the provisions of state of law about the ulayat land rights/communal land of Sentani from 9 tribe on 12 customary area. The perception then without seeing there still other law which are "customary law/customary land law" as the living law with the values of culture, is being the basis of implementation of Sentani customary community regulation over the control rights and ownership of the customary land/ulayat land in generations. This can be seen from the view of Sentani culture values over the land which giving a Symbolic terms, that the land is mother (mamaku) which always act as the giver of life and the entire universe at Tabi customary territory. In Sentani customary law, the land is the basis on regulating the birthright of each Sentani person/clan in the structure of kinship system and customary institution based on the 12 customary areas, with the main principle of the validity of rights to customary land/communal land, which based on the principle of Territorial Genealogy and Marriage.

Even though, the existence of companies at 12 customary land, the condition always on the context which still there's no same perception about the rights over state land and ulayat/communal rights over the land which regulated by dualism of legal system, which are state law/Basic Agrarian Law and customary land law in 12 region between the control of state/Indonesia government and Sentani customary communities which still doesn't have same perception.

Objectively the understanding of companies toward the control, utilization, or management rights and the ownership rights of customary land or ulayat land which in the realm of customary law over the customary land and its cultural values of Sentani indigenous people, honestly still limited to the understanding of certain individual employee. So that there is no complete understanding for every employee of the company on the object of research in this study. therefore, for the employee of the company needed a program to understand the ethnography and customary law of 9 customary communities in 12 customary areas of Jayapura holistically and comprehensively in institutionally through company department which related with social infrastructure of people programs in the field with OPD/SKPD of Jayapura Government.

\section{Conclusion}

a. The culture knowledge of 9 tribe of Sentani indigenous people in 12 sub customary area on the Tabi customary area at Jayapura, understand about ulayat and communal rights over the land which are the same as the legal subject and legal object. It is just different on the implementation on the social

The Legal Standing of Ulayat Rights and Communal Rights of a Land Based on Knowledge and Kindship of Community System of the Sentani 
structure on other tribe and clan, which the ulayat rights were held by the tribe as the public rights and private rights over the borders of customary external area and sub internal customary areas with tribe and clan of fellow customary law communities or neighboring customary law communities. While communal rights were held by the clan with limitation by public and private rights.

b. That the ulayat and communal rights over the land position in the kinship system of customary communities of Sentani still dominated by a man based on the patrilineal system as the holder of birthright including control, utilization, and ownership right over the ulayat lands and/or communal land from 9 tribe of Sentani indigenous people in 12 sub customary area (Tabi customary area) on 4 development areas of Jayapura.

c. The implementation of ulayat and communal rights over the land in the environment of 9 tribes of indigenous people in 12 customary areas in which the Sentani indigenous people have legal implication for the perception differences between Sentani customary communities, bureaucracy, Basic Agrarian Law/ Minister of Agrarian and Spatial Planning Regulations/Head of State Land Agency No. 10 of 2016 on its implementation. For the Sentani customary people the position of ulayat and communal rights is on the same legal subject which held by the tribe as the public rights while the implementation of communal rights held by the clan as private rights. For bureaucrat/company communal and ulayat rights have the same position as control, utilization, and ownership rights by state in accordance with Article 3 of Constitution 1945 without limitation of communal/ulayat rights for customary people.

d. The legal implication toward ulayat and communal rights over tall the Regional Regulations which named "Ulayat Rights" regulation from province, district/city, while with the issuance of Minister of Agrarian and Spatial Planning Regulations/Head of State Land Agency No. 10 of 2016 on its implementation also on the regional regulation of ulayat rights with the content material in terms of legal subjects and legal objects.

\section{References}

Arba, Hukum Tata Ruang Dan Tata Guna Tanah (Prinsip-Prinsip Hukum Perencanaan Peantaan Ruang dan Penatagunaan Tanah), Sinar Grafika, 2017.

Ap, Lemech, Kemajemukan Hukum Dalam Penyelesaian Sengketa atas Tanah Adat Pada Orang Dani di Jayawijaya. Tesis Pasca sarjana (S2), Jakarta Program Pasca sarjana Universitas Indonesia (UI). 1994

Arief, S Asas-Asas Hukum Adat dan Kumpulan Kuliah Hukum Adat. Pustaka Tinta Mas, Surabaya. 1986

Arifandi Mohammad, et. al. Hash Penelitian dan Pengumpulan Data Lapangan Hukum Adat atas Tanah Pada Kabupaten Daerah Tingkat II Biak Numfor, Laporan Penelitian, Proyek Penelitian Hukum Adat Tanah di Propinsi Irian Jaya. 1980.

Beanal, N. Lidya Arti Tanah Menurut Suku Amungme, Forum Lorentz. 1999

Beanal, Tom Amungme "Magaboarat Negel Jornbei-Peibei “, Jakarta, WALHI

Billah M.M, 1997 Dua Abad Penguasaan Tanah, Pola Penguasaan Tanah Pertanian di Jawa dan Masa ke Masa, Sediono M.D. Tjondronegoro (ed). Jakarta, Gramedia.1984

BPN-IRJA Perlindungan Hukum oleh Negara Terhadap Hak-Hak Milik Masyarakat Adat Atas Tanah. Makalah Workshop Sehar LBH Papua. 1999

Budhisantoso. S., et.al. Masyarakat Terasing Amungrne di. Irian Jaya. Jakarta, Proyek Pengkajian dan Pembinaan Nilai Tradisional Direktorat Jenderal Kebudayaan. Depdikbud RI.1995.

Cook Traditional Tribal Land Tenure and The Effects od Development A Case Study of The Amungme of Irian Jaya Indonesia, USA Washington State University. 1988

Coepen, J OFM Enkele Aspecten van de Geestelijke Cultuur Van de Waropen. Jayapura Mimeo. 1963

Dep. Transmigrasi RI Himpunan Unit Pemukiman Transmigrasi Irian Jaya. Jayapura. 1984

Dominikus Rato, Hukum Benda dan Harta Kekayaan Adat, LaksBang PRESSindo, Yogyakarta,.

Elkin, A.P. Review of Research in Social Anthropologi. Papuan/Melanesia Section, South Pasific Comission, Report on Project S.5 (B) no 1 University, of Sydney. 1950

Erarri, Phil Karel Tanah Kita, Hidup Kita, Jakarta, Pustaka Sinar Harapan. 1999

F 0 X, Robin Kinship and Marriage. Books Ltd, New York USA. 1981

Galis, K.W. English Summary of Papoe 's van de Humboldt Baai” Bijdrage law, Journal Pluralism, 1955.

The Legal Standing of Ulayat Rights and Communal Rights of a Land Based on Knowledge and Kindship of Community System of the Sentani

Customary Law in Jayapura Regency, Papua 
Gobai, Nato Beberapa Aspek Pandangan Hidup di Alam Waropen dan Pengaruhnya Terhadap Arus Perkembangan Jaman. Makalah tidak terbit. Gereja Paroki Timika-Agimuga. 1987

Geertz C the Impact of Concept of Culture on the Concpet of Man. Chicago University Press. 1966

Hetaria M. Pembebasan Tanah Adat untuk Pelaksanaan Pembangunan Fisik di Kecamatan Abepura; Khususnya di Wilayah Tanah Adat Masyarakal Nafri. Laporan Penelitian F.H-UNCEN. 1991

I Nyoman Nurjaya, Politik Hukum Pengakuan Hak Ulayat, Kencana, 2018.

Kareth Ferry Pemilikan Tanah Adat dan Pembangunan di Irian Jayü', Makalah, Jayapura, Fakultas Hukum UNCEN. 1994.

Koentjaraningrat \& Harja W.Bachtiar, Penduduk Irian Barat. Jakarta: UI. 1963

Koentjaraningrat Irian Jaya : Membangun Masyarakat Majemuk, Jakarta: Djambatan. 1993

Kelompok Peneliti Etnografi Irian Jaya ,1993 Etnografi Irian Jaya Panduan Sosial Budaya. Jayapura: Buku Satu Kelompok Penelitian Etnografi Irian Jaya

Mamapaku Richo. M.Ndaitita : Sebagai Prinsip Umum yang nampak dalam lima aspek Kebudayaan orang-orang Waropen. Jayapura: STTK Academic essay. 1982

Mampioper, Niesje A. Mengenal Beberapa Aspek Kebudayaan Suku Dani, Jayapura : Biro Kesejahteraan Rakyat Sekretariat Wilayah Daerah Tingkat I Irian Jaya.1958

Mampioper, Arnold Amungme "Manusia Utama Dani Nemangkawi Pegunungan Cartenz", Tembagapura, PT. Freeport Indonesia.2000

Manembu, Niesje A. Suku Sempan, Nakai, Nduga, dan Amungme di Kawasan Lorenz:, Jayapura WWF.1991

Mansoben J.R Sistem Politik Tradisional di Propinsi Irian Jaya, LIPI dan RUL.1995

Muhammad, Bushar Pokok-Pokok Hukum Ada!, cet. Kelima. PT. Pradnya Paramita, Jakarta.1991

Naffi Sanggenafa, Masyarakat Waropen Di Pantai Timur Teluk Cenderawasih, dalam Koentjaraningrat, Irian Jaya : Membangun Masyarakat Majemuk. Jakarta, Penerbit Djambatan Anggota IKAP, 1994.

Patty, Samuel, A. Adat dan Upacara Perkawinan Daerah Irian Jaya, Proyek IDKT 1979/1980. Dirjen Kebudayaan Departemen Pendidikan dan KebudayaanJakarta. 1980

Pospisil, L. Kapauku Papuans and their Law, New Haven, Yale UniversityPublication in Anthropology, 1958.

Pouwer, J. Enkele Aspecten van de Mimica Cultuur. The Hague: Staatsdrukkerij.1958

R. Yando Zakaria, Etnografi Tanah Adat (Konsep-Konsep Dasar dan Pedoman Kajian Lapangan), Agrarian Resources Center (ARC), 2018.

Rosnidar Sembiring, Hukum Pertanahan Adat, PT. Raja Garfindo Persada, 2017.

Reumi, Frans, dkk. Prinsip-Prinsip Kekerabatan Dalam Penyelesaian Sengketa Tanah Ulayat Pada Suku Amungme di Timika Irian Jaya. Jakarta, DIKTI.1998

-------------,Hukum Adat Suku Amungme di Timika Irian Jaya, Tembagapura, PT. Freeport Indonesia. 1999

---------------,Hukum Adat Tanah di Irian Jaya. Kerjasama Perguruan Tinggi se Indonesia Timur di Palu. DIKTI, Jakarta, 1999

--------------,Identifikasi Pemetaan Hak Ulayat pada Masyarakat Hukum adat Waropen. LEMLIT UNCEN Jayapura.2007

SADP-IRJA Identifikasi Potensi, Kendala dan Peluang Sistem Usaha Tani Berbasis Perkebunan di Irian Jaya. Laporan Penelitian, Jayapura. Soehendra Djaka. 1998

------------,Proses Pembangunan dan Implikasinya Situasi Yang Berfokus Pada “sistem” Kekerabatan Penduduk Desa Tabbeyan di kabupaten Jayapura, Thesis Program Pasca sarjana Universitas Indonesia. 1991

Soepomo Bab-bab Tentang Hukum Adat, Cet. Kesepuluh, PT. Pradnya Paramita, Jakarta.1980.

Supriyoko Masih Miskin, Penelitian Sosio-Kultural Pertanahan. Suara Pembaharuan, Jakarta.1980

Sarkawi, Hukum PembebasanTanah Hak Milik Adat Untuk Pembangunan Kepentingan Umum, Graha Ilmu, 2014.

Teer Haar, B. Asas-asas dan Susunan Hukum Adat. Pradnya Paramita, Jakarta. Trebken Such, F. 1980 Border Areas of Asmat: The Waropen Asmat Sketchhbook No. 1 Agats L: Museum Asmat, 1970.

The Legal Standing of Ulayat Rights and Communal Rights of a Land Based on Knowledge and Kindship of Community System of the Sentani

Customary Law in Jayapura Regency, Papua 
Wanggai Frans Aspek Lingkungan Dan Pengembangan Kawasan Biak, Jayawijaya, Timika dan Jayapura, Makalah Seminar dan Lokakarya Pembangunan Irian Jaya tanggal 6-9 Desember 1995. Jayapura, LIPI, PEMDA danUNCEN.1996

Widjojo Muridan S Orang Kamoro dan Perubahan Lingkungan Sosial Budaya di Timika Irian Jaya, Jakarta, PMB, LIPI.1997

Yulfita Raharjo, et. al., Sumber Daya Manusia dan Pembangunan Irian Jaya, Makalah Seminar dan Lokakarya Pembangunan Irian Jaya tanggal 6-9 Desember Tahun 1995, Jayapura ; LIPI, PEMDA dan UNCEN.1995.

\section{Copyrights}

Copyright for this article is retained by the author(s), with first publication rights granted to the journal.

This is an open-access article distributed under the terms and conditions of the Creative Commons Attribution license (http://creativecommons.org/licenses/by/4.0/). 